\title{
Biological Enrichment of Chromite ore on Alkaline Roasting Using Seidlitzia rosmarinus ash
}

\section{SEDIGHE SADAT MARJANI*, MOHAMMAD HAKIMI and HASAN ALI HOSSAINI}

Department of Chemistry, Payame Noor University, 19395-4697 Tehran, Iran.

*Corresponding author E-mail: marjanisediqe@yahoo.com

http://dx.doi.org/10.13005/ojc/340162

(Received: June 07, 2017; Accepted: November 15, 2017)

\begin{abstract}
The Eco-friendly methods have become a promising synthetic strategy in science and technology in recent years. The current study describes alkaline roasting of chromite ore using Seidlitzia rosmarinus ash and water leaching of resulting cake. The Formation of $\mathrm{Na}_{2} \mathrm{CrO}_{4}$ was confirmed by Existing of ligand to metal charge transfer (LMCT) band in the UV-visible spectrum in 270 and $370 \mathrm{~nm}$. Rhombohedral structure of the product was investigated using the powder X-ray diffraction (PXRD). The X-ray Fluorescence Spectroscopy (XRF) shows Increasing in chromium percent from 44.94 to 65.07 and existing elementals as sodium, potassium, calcium and magnesium in $S$. Rosmarinus ash that can act as alkaline assistance in alkaline roasting.
\end{abstract}

Key words : Biological, Enrichment, Chromite, Seidlitzia rosmarinus.

\section{INTRODUCTION}

Chromium and its by products have broad applications as stainless steel production, chromic acid plating, corrosion control and etc. ${ }^{1-3}$ chromium is present in many minerals, occasionally combined with iron oxides and other transition metal oxides such as manganese, titanium, vanadium, niobium and etc 4 .

Chromite ore belongs to the spinel group with the general chemical formula of $\mathrm{XY}_{2} \mathrm{O}_{4}$ which $X$ and $Y$ represent divalent and trivalent metal ions the natural mineral is usually represented by the general formula $\left(\mathrm{Fe}^{2+}, \mathrm{Mg}\right)\left(\mathrm{Cr}, \mathrm{Al}, \mathrm{Fe}^{3+}\right)_{2} \mathrm{O}_{4}$ with sometimes small quantities of Magnesium, Titanium and Vanadium ${ }^{5}$.

Production of sodium chromate from chromite ore is requisite reaction for producing other products ${ }^{6}$. sodium chromate was manufactured by leaching of chromite ore using sodium hydroxide and sodium carbonate at temperatures $1000^{\circ} \mathrm{C}$ in an atmosphere of oxygen ${ }^{7,8}$. A process such as soda- ash roasting ${ }^{9}$, acid leaching ${ }^{10}$, alkaline leaching ${ }^{11,12}$, alkaline roasting using sodium 
hydroxide, potassium hydroxide and water leaching ${ }^{13}$, have been developed for the processing of chromite ore in order to produce sodium chromate.

The conventional methods such as Pyrometallurgy or Hydrometallurgy, are not economic and ecofriendly. therefore Bioleaching of minerals is a suitable way for solving these problems. recently bioleaching of ores using microorganisms was reported ${ }^{14}$.

In this study, leaves and branches of S. Rosmarinus in oxidizing atmosphere was used as environmentally friendly and economical source for alkaline roasting of chromite and resulting solid cake was dissolved in distilled water to remove insoluble Iron (III) oxide and magnesium oxide from soluble chromates.

\section{EXPERIMENTAL METHODOLOGY}

The Concentrated chromite was obtained from a sabzan mine of faran, Kerman, Iran. The composition of concentrate sample used is given in Table. 1. Concentrate was sieved into 200 mesh. $S$. Rosmarinus Leaves was collected from desert of bajestan, Khorasan, Iran.

The $S$. Rosmarinus leaves were cleaned with double distilled water, shade-dried and ground to powder and stored for further study. $3.3 \mathrm{~g}$ of chromite ore and $6.6 \mathrm{~g}$ of grinding plant was wearing up and uniformed. The mixture was transferred to crucible and putting up in $1100{ }^{\circ} \mathrm{C}$ for 2 hours. Roasting mixture Chromite was cold and wear up in pounder and then mixed with water in $50 \mathrm{ml}$ flask with fixed temperature $60^{\circ} \mathrm{C}$ in presence magnetic stirrer.

The UV-vis spectrum was recorded on a double beam spectrophotometer (Shimadzu, model UV-2550) from 200 to $500 \mathrm{~nm}$. The solution was filtered, concentrated and dried in an oven for further analysis. Element Analysis of solid sample was confirmed by ED 2000 belong Oxford company of
England X-ray Fluorescence (XRF) Spectrometer. for evaluation of the mineral structure of sodium chromate, X-ray powder diffraction using $\mathrm{Cu}-\mathrm{K} \alpha$

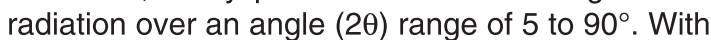
step: 0.04 with the support of $X$ 'Pert software was used.

\section{RESULTS AND DISCUSSION}

\section{Characterization of chromite ore}

The original mineral phase in chromite is $\mathrm{FeCr}_{2} \mathrm{O}_{4}$.also existence of trace of titanium. nickel and manganese has been proven ${ }^{15}$.

The elemental analysis results of chromium have shown in Table. 1. this result shows that the most percentage of elements respectively belong to chromium, silicon, iron and magnesium.

\section{Characterization of S. Rosmarinus ash}

Chemical compositions of roasted plant in $1100{ }^{\circ} \mathrm{C}$ determined by XRF and were shown in Table 2. this result shows the existence of elements such as sodium, potassium, calcium, magnesium and strontium that confirmed alkaline assistance role of $S$. Rosmarinus ash.

The comparison, chemical composition of chromium, S. Rosmarinus and soluble chromates in table 1,2 and 3, show a large percentage of chromium has been belonging to $\mathrm{SiO}_{2}$, that destroyed during the process. deletion of $\mathrm{Fe}_{2} \mathrm{O}_{3}$ and decreasing in the percentage of magnesium show formation of insoluble compound as $\mathrm{Fe}_{2} \mathrm{O}_{3}$ and $\mathrm{MgO}$. Low change in the percentage of potassium and sodium, and increase in the percentage of chromium, confirm the formation of soluble chromates as $\mathrm{Na}_{2} \mathrm{CrO}_{4}$ and $\mathrm{K}_{2} \mathrm{CrO}_{4}$.

The Comparison chemical composition of S. Rosmarinus ash and soluble chromates in Table. 2 and 3 show decrease in the percentage of elements as calcium, strontium and magnesium, that Proves formation of insoluble chromates include $\mathrm{CaCrO}_{4}, \mathrm{MgCrO}_{4}$ and $\mathrm{SrCrO}_{4}$. This changes justified by equation 1 to 7 .

Table. 1: Chemical composition of chromite by XRF

\begin{tabular}{llllllllllll}
\hline Compound & $\mathrm{Cr}_{2} \mathrm{O}_{3}$ & $\mathrm{SiO}_{2}$ & $\mathrm{Fe}_{2} \mathrm{O}_{3}$ & $\mathrm{MgO}$ & $\mathrm{Al}_{2} \mathrm{O}_{3}$ & $\mathrm{SO}_{3}$ & $\mathrm{P}_{2} \mathrm{O}_{5}$ & $\mathrm{MnO}$ & $\mathrm{CaO}$ & $\mathrm{TiO}_{2}$ & $\mathrm{NiO}$ \\
\hline Percentage & 44.94 & 20.47 & 18.89 & 10.06 & 2.91 & 0.56 & 0.55 & 0.45 & 0.22 & 0.16 & 0.16 \\
\hline
\end{tabular}


Table. 2: chemical composition of $\boldsymbol{S}$. Rosmarinus was determined by XRF

\begin{tabular}{llllllllllllll}
\hline Compound & $\mathrm{CaO}$ & $\mathrm{SiO}_{2}$ & $\mathrm{~K}_{2} \mathrm{O}$ & $\mathrm{Na}_{2} \mathrm{O}$ & $\mathrm{MgO}$ & $\mathrm{SO}_{3}$ & $\mathrm{Cl}$ & $\mathrm{Fe}_{2} \mathrm{O}_{3}$ & $\mathrm{Al}_{2} \mathrm{O}_{3}$ & $\mathrm{SrO}$ & $\mathrm{TiO}_{2}$ & $\mathrm{MnO}$ & other \\
\hline Percentage & 31.63 & 18.05 & 11.32 & 8.49 & 7.67 & 7.23 & 4.6 & 4.97 & 3.34 & 0.71 & 0.54 & 0.54 & 0.48 \\
\hline
\end{tabular}

Roasting of chromite using S. Rosmarinus ash and leaching with water

Table. 3: Chemical composition of soluble chromates produced by roasting using S. Rosmarinus and leaching with water

\begin{tabular}{lccccccccccc}
\hline Compound & $\mathrm{Cr}_{2} \mathrm{O}_{3}$ & $\mathrm{SO}_{3}$ & $\mathrm{Na}_{2} \mathrm{O}$ & $\mathrm{K}_{2} \mathrm{O}$ & $\mathrm{Cl}$ & $\mathrm{MgO}$ & $\mathrm{Al}_{2} \mathrm{O}_{3}$ & $\mathrm{CaO}$ & $\mathrm{SiO}_{2}$ & $\mathrm{MnO}^{2}$ & $\mathrm{Sb}_{2} \mathrm{O}_{3}$ \\
\hline Percentage & 65.07 & 13.66 & 7.52 & 6.18 & 2.83 & 1.87 & 1.26 & 0.42 & 0.38 & 0.23 & 0.18 \\
\hline
\end{tabular}

Meanwhile roasting of chromite, probable reaction was accrued that equation 1 to 7 shows this process.

( $\mathrm{M}$ is Representative of alkali metals )

$$
\begin{aligned}
& \mathrm{FeCr}_{2} \mathrm{O}_{4}+4 \mathrm{MOH}+\frac{7}{4} \mathrm{O}_{2} \rightarrow \frac{1}{2} \mathrm{Fe}_{2} \mathrm{O}_{3}+2 \mathrm{M}_{2} \mathrm{CrO}_{4}+2 \mathrm{H}_{2} \mathrm{O} \\
& \mathrm{MgCr}_{2} \mathrm{O}_{4}+4 \mathrm{MOH}+\frac{3}{2} \mathrm{O}_{2} \rightarrow \mathrm{MgO}+2 \mathrm{M}_{2} \mathrm{CrO}_{4}+2 \mathrm{H}_{2} \mathrm{O} \\
& \mathrm{FeAl}_{2} \mathrm{O}_{4}+2 \mathrm{MOH}+\frac{7}{4} \mathrm{O}_{2} \rightarrow \frac{1}{2} \mathrm{Fe}_{2} \mathrm{O}_{3}+2 \mathrm{MAIO}_{2}+\mathrm{H}_{2} \mathrm{O} \\
& \mathrm{MgAl}_{2} \mathrm{O}_{4}+2 \mathrm{MOH} \rightarrow \mathrm{MgO}+2 \mathrm{MAIO}_{2}+\mathrm{H}_{2} \mathrm{O} \\
& \mathrm{SiO}_{2}+2 \mathrm{MOH} \rightarrow \mathrm{M}_{2} \mathrm{SiO}_{3}+\mathrm{H}_{2} \mathrm{O} \\
& \mathrm{Fe}_{3} \mathrm{O}_{4}+3 \mathrm{MOH}+\frac{1}{4} \mathrm{O}_{2} \rightarrow 3 \mathrm{MFeO}_{2}+\frac{3}{2} \mathrm{H}_{2} \mathrm{O} \\
& \mathrm{MgFe}_{2} \mathrm{O}_{4}+2 \mathrm{MOH} \rightarrow \mathrm{MgO}+\mathrm{MFeO}_{2}+\mathrm{H}_{2} \mathrm{O}
\end{aligned}
$$

equation 3-6 show possibility reaction of some of impurities as $\mathrm{SiO}_{2}, \mathrm{FeAl}_{2} \mathrm{O}_{4}$ and

$\mathrm{MgFe}_{2} \mathrm{O}_{4}$ with $\mathrm{MOH}$, but " $\mathrm{G}$ in equation 1 and 2 is more negative therefore the formation of chromates is more likely ${ }^{16}$.

\section{Analysis of UV-vis spectroscopy}

The UV-vis pattern of $\mathrm{Na}_{2} \mathrm{CrO}_{4}$ in Fig. 1 showed bands in 270 and $370 \mathrm{~nm}$ mainly attributed to ligand -to -metal charge transfer (LMCT) band ${ }^{17}$.

\section{XRD studies}

Figure.2 shows XRD Pattern of sodium chromate. Intense peaks at the various angular position which indexed to JCPDS 22-1365 was attributed to $\mathrm{Na}_{2} \mathrm{CrO}_{4}$ with orthorhombic structure and network Parameters $a=7.1462 b=9.2635$, $\mathrm{c}=5.864$, existence a few impurities $\mathrm{Na}_{0.2} \mathrm{~K}_{0.8} \mathrm{CrO}_{4}$ with monoclinic structure and network parameters $a=9.939, b=5.625, c=7.163$ were confirmed $^{18}$.

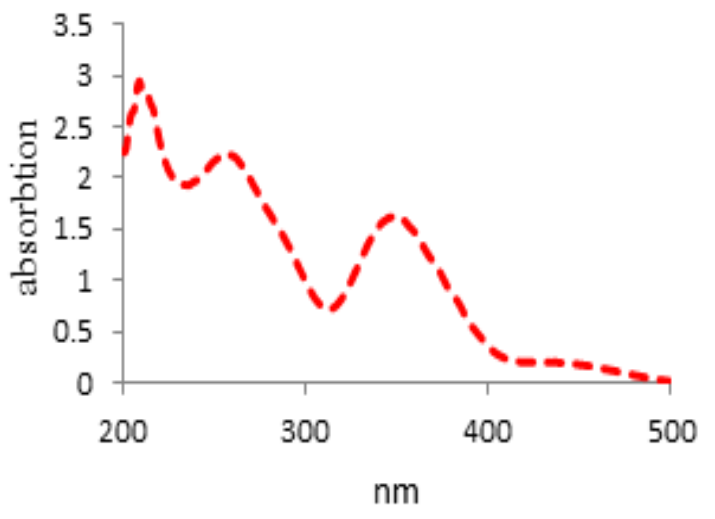

Fig.1. UV-Vis spectrum of sodium chromate

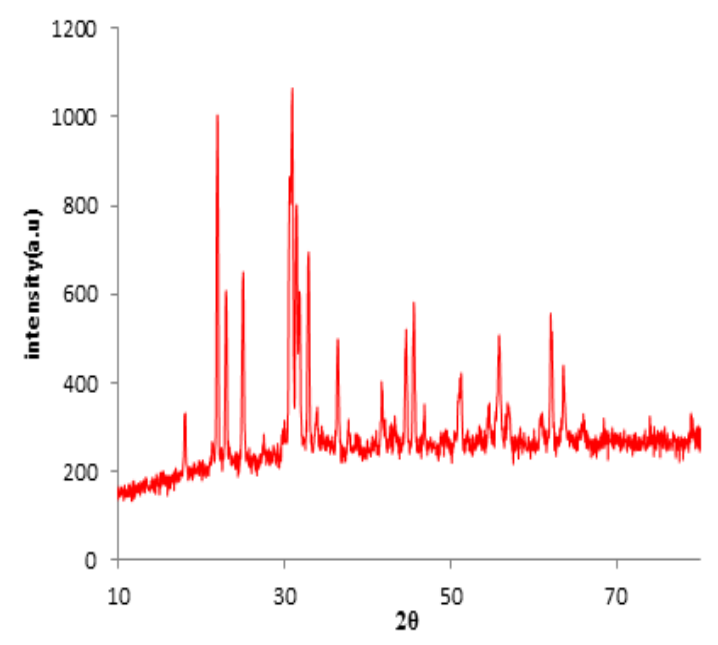

Fig. 2. XRD spectrum of $\mathrm{Na}_{2} \mathrm{CrO}_{4}$ 


\section{CONCLUSION}

In summary, the conversion of chromite ore to soluble chromates was achieved in two steps, alkali roasting by $S$. Rosmarinus ash and water leaching. XRF studies showed increases in the percentage of chromium from 44.94 to 65.07 .
Therefore S. Rosmarinus ash could act as Leach suppliers. UV-vis studies showed three picks due to charge transfers that confirmed formation of sodium chromate. The results obtained from XRD studies showed indicator picks due to orthorhombic structure of $\mathrm{Na}_{2} \mathrm{CrO}_{4}$.

\section{REFRENCES}

1. Barnhart ,J.; J. soil contamination. 1997, 6, 9. Tathavadkar ,V.D.; Jha, A.;Antony, M.J.Metal 561-568.

2. Dennis, J.K.; Such, T.E. J. Woodhead Publishing.1993,3,206-240.

Mater Trans B,2001, 32,593-602.

10. Gevice, A.; Topkayay, A.Y.; J.Miner .Eng, 2002, $15,885-888$.

3. Chen, G.; Wang, J.; Wang, X.; Zheng, S.L.; $\quad$ 11. Xu, H. J. Miner Eng, 2005, 18,527-535. Du, H.; Zhang, Y.J. Hydrometallurgy. 2013, 139, 46-53.

4. Sanchez,S.S.; Makanyire, T.; Escudero,C.L.; Hara,Y.; Jha, A.J. Green. Chem . 2015, 17, 2059-2080.

12. Zhang,Y. J.Trans .Nonferrous. Metals. Soc. China. 2010,20,888-891.

13. Amolpornwijit,W.; Meegoda,J.N.; Hu,Z.J. Pract. Period. Hazard. Toxic Radioact. Waste Manag. 2007, 11, 234-239.

5. prirenyatwa,S.; Escudero,C.L.; Sanchez,S.S.; Hara,Y.; Jha,A.J.Hydrometallurgy. 2015, 4137, 14.

6. Gu, F.; Wills, B.A. J. Miner. Eng.1988, 1, 235240.

7. Copson,R.L. J.Reinhold,1956,8,262-282.

8. Mark,H.F.; Othmer, D.F.; Overberger,C.G.; Seaborg,G.T.; Grayson, M.; J.Kirk-Othmer Encyclopedia of Chemical Technology, 1979,3, 82-120.

14. Ajim ,S.; Sutar,S.D. J. Int. Environ. Sci. Technol. $2015,5,14-21$.

15. Ji, Z.J. Inorg. Chem. Ind. 2012, 44, 1-5.

16. Hwang,J.Y.; Seo,D.S. J.Electrochem. Society. 2010, 157,351-357.

17. Woodward,D. Molecular Orbital Theory and Charge Transfer Excitations Chemistry, 2008 ,123 Spring.

18. Dettmer,A.; Nunes,K.; Gutterres.M.; Romeu,M.N.J. chem Eng. 2010, 160,8-12. 